JOTE Volume 3 Nomor 1 Tahun 2021 Halaman 65-70

JOURNAL ON TEACHER EDUCATION

Research \& Learning in Faculty of Education

\title{
IMPLEMENTASI CREATIVE, CRITICAL THINGKING, COMMUNICATIVE, COLLABORATIVE (4C) DALAM PENDEKATAN SAINTIFIK PADA PEMBELAJARAN SEJARAH INDONESIA KELAS X IK MAN 1 SOLOK
}

\author{
Putri Permata Sari ${ }^{1}$, Buchari Nurdin ${ }^{2}$, Kaksim $^{3}$ \\ Program Studi Pendidikan Sejarah, STKIP PGRI Sumatera Barat \\ Email : putripermatasari045@gmail.com
}

\begin{abstract}
Abstrak
Pelaksanaan pembelajaran Creative, Critical Thingking, Communicative, Collaborative, yang digunakan guru sejarah dalam menekankan keterampilan siswa kelas X IK di MAN 1 Solok. Pengaplikasian 4C ini siswa dituntut lebih berpikir kritis dalam menganalisa materi dan menyampaikan pemikiran serta mengembangkan ide baru. Tujuan penelitian ini yaitu mendeskripsikan rancangan, pelaksanaan, cara guru mengevaluasi pembelajaran 4C dalam pembelajaran sejarah Indonesia kelas X IK di MAN 1 Solok. Metode yang digunakan yaitu, metode kualitatif dengan tipe deskriptif. Hasil penelitian rancangan pembelajaran 4C yaitu mengumpulkan informasi terkait materi, menganalisis materi yang sudah dikumpulkan, mengemukakan hasil analisis, mendiskusikan materi pembelajaran. Pelaksanaan pembelajaran $4 \mathrm{C}$ yang dilakukan guru meliputi kegiatan guru menjelaskan terlebih dahulu tujuan pembelajaran, guru memberikan siswa kesempatan untuk menganalisis materi, siswa bersama guru menarik kesimpulan diakhir pembelajaran. (3) Evaluasi yang dilakukan guru menggunakan $4 \mathrm{C}$ yaitu guru memberikan pertanyaan disetiap akhir pembelajaran, siswa diberikan tugas berbentuk Mind Mapping, jenis soal yang digunakan guru Low, Middle, HOTS.
\end{abstract}

Kata Kunci: Pelaksanaan, Model 4C, Pendekatan Saintifik

\begin{abstract}
Performance of creative study, critical thingking communicative, comparative the history teacher used in emphasizing the skill of $\mathrm{x}$ class students at man 1 solok. Applying the $4 \mathrm{c}$ application requires more critical thinking in analyzing the material and communicating thoughts and developing new ideas. The purpose of this study is to describe design, implement, how quru evaluates learning $4 \mathrm{c}$ in the Indonesian history of the first class at solok. The method used is, qualitative methods with descriptive types. The study of the $4 \mathrm{c}$ design of learning is to collect information-related information, analyze the collected material, come up with an analysis, discuss the learning materials. The performance of teacher $4 \mathrm{c}$ learning includes teacher activities explaining the purpose of learning first, teachers giving students an opportunity to analyze the material, students with teachers drawing conclusions at the end of the
\end{abstract}


study. (3) a teacher's evaluation USES $4 \mathrm{c}$ as quru asking questions on each end of the study, students are given mental mapping assignments that teachers low, middle, hots do.

\section{Keywords: Implementation, 4C Model, Scientific Approach}

\section{PENDAHULUAN}

Suatu sikap dan perilaku individu atau sekelompok manusia dalam upaya pendewasaan seorang manusia melewati pembelajaran serta latihan tindakan yang bersifat mendidik disebut pendidikan. Dalam memenuhi tujuan pendidikan nasional yang terdapat dalam Undang-Undang Nomor 20 tahun 2003 tentang Sistem Pendidikan Nasional, Pasal 3 dijelaskan bahwa: pendidikan nasional berfungsi mengembangkan kemampuan dan membentuk karakter serta peradaban bangsa yang memiliki martabat untuk mewujudkan mencerdaskan kehidupan bangsa, bertujuan untuk berkembangnya potensi peserta didik agar menjadi manusia yang beriman dan bertakwa kepada Tuhan Yang Maha Esa, berakhlak mulia, sehat, berilmu, cakap, kreatif, mandiri dan menjadi warga Negara yang demokratis serta bertanggung jawab. Pendidikan di sekolah dilaksanakan berpedoman pada kurikulum yang digunakan.

Pada kurikulum 2013 terjadi perubahan pada Permendikbud nomor 20 tahun 2016. Perubahannya adalah tentang keterampilan yang sangat diperlukan oleh anak-anak bangsa. Dan oleh karena itu diperlukan keterlibatan semua pihak terutama pihak sekolah dalam menyiapkan anak-anak bangsa agar memiliki keterampilan yang diperlukan dalam kehidupan abad 21 saat ini. Agar bisa beradaptasi pada era globalisasi di abad 21 ini maka setiap warga Negara dituntut untuk memiliki kemampuan yang dapat menjawab tuntutan perkembangan zaman.

Era globalisasi yang berjalan pada saat ini mendorong ilmu pengetahuan dan teknologi yang berkembang sangat cepat dan semakin canggih, dengan peran yang makin luas maka diperlukannya guru yang memiliki karakter. Semua orang yang tidak siap dengan perubahan ilmu pengetahuan dan teknologi ini tidak akan maju. Maka dari itu mutu pendidikan harus ditingkatkan. Sekolah yang menjadi lembaga utama dalam pendidikan dituntut untuk memiliki keterampilan berpikir kreatif, berpikir kritis, berkomunikasi dan berkolaborasi atau biasa dikenal dengan 4C.

Hal ini juga menuntut guru mempunyai peranan yang sangat penting untuk mencapai keberhasilan belajar yang lebih baik dengan mengembangkan keterampilan peserta didik. Guru merupakan salah satu profesi yang sangat luar biasa, sehingga yang dapat menekuni profesi sebagai guru bukanlah sesuatu yang mudah bagi semua orang. Banyak persoalan dan rintangan yang harus dilalui untuk mendapat gelar sebagai seorang guru yang professional. Selain itu, tugas utama seorang guru adalah untuk menyalurkan ilmu yang selama ini di dapatkan kepada peserta didik di sekolah, tidak hanya di dalam kelas tapi juga di luar kelas. Hal ini juga didukung dengan diterapkan sistem pembelajaran yang tidak hanya terfokus pada Hard Skill saja tapi juga diterapkan pembelajaran yang 
mengutamakan Soft Skill. Dalam proses pembelajaran selanjutnya diterapkan Creative, Critical Thingking, Communicative, dan Collaborative (4C).

Hal ini lah yang mendorong MAN 1 Solok menerapkan 4C dalam proses pembelajaran sesuai dengan kurikulum 2013 revisi yang digunakan sekolah ini. Dengan harapan peserta didik bisa mengikuti perkembangan zaman dan memiliki keterampilan yang dapat digunakan untuk kehidupan di masa depan. Yang tidak hanya menguasai ilmu pengetahuan saja tapi juga menguasai teknolgi yang ada.

Berdasarkan pengamatan dilapangan pengaplikasian pembelajaran 4C yang diterapkan oleh guru lebih menekankan keterampilan siswa dalam proses pembelajaran yang sesuai dengan pembelajaran sejarah di sekolah. Dimana dalam pengaplikasian $4 \mathrm{C}$ ini siswa di tuntut untuk lebih bisa berpikir kritis dalam menganalisa materi pembelajaran lalu menyampaikan hasil pemikirannya sesuai dengan komunikasi yang baik, selain itu siswa juga harus bisa mengembangkan ide-ide baru dan membangun jiwa sosial yang baik. Maka dari itu perlu dilakukan pendalaman dan diperluas sekaligus menyelaraskan berbagai program dan kegiatan pendidikan 4C yang sudah difasilitasi oleh guru sehingga terlaksana sekarang.

Berdasarkan permasalahan tersebut, penelitian ini dilakukan untuk mengetahui implementasi Creative, Critical Thingking, Communicative, And Collaborative (4C) dalam kegiatan pembelajaran Sejarah Indonesia siswa kelas $\mathrm{X}$ IK MAN 1 Solok. Alasan penulis memilih MAN 1 Solok sebagai tempat penelitian karena MAN 1 Solok telah menerapkan pembelajaran $4 \mathrm{C}$ ini dalam proses pembelajaran. Untuk itu penelitian ini berjudul "Implementasi Creative, Critical Thingking, Communicative, And Collaborative (4C) Dalam Pendekatan Saintifik Pada Pembelajaran Sejarah Indonesia Kelas X IK Di MAN 1 Solok".

Menurut Deta dalam Jenner Simarmata, dkk (2020: 48) pembelajaran 4C adalah solusi yang diperlukan untuk masalah kompleks abad ke 21 yang membutuhkan berbagai keterampilan yang terkait dengan pemikiran kritis, inovasi, dan kreativitas. Kreativitas dan inovasi dari suatu masalah dan menghasilkan produk sebagai hasil dari pemikiran baru. Keterampilan belajar dan inovasi pembelajaran memfasilitaskan penugasan keterampilan lain seperti kemampuan mengenali perspektif, menggunakan ide, mengambil tindakan kreatif dan relevan untuk memecahkan masalah yang kompleks.

Teori kognitif menurut (Gagne, 1976: 12-39) adalah proses yang terjadi secara internal di dalam pusat susunan syaraf pada waktu manusia sedang berpikir. Selain itu pengertian teori kognitif merupakan sebuah istilah yang digunakan oleh psikolog untuk menjelaskan semua aktivitas mental yang berhubungan dengan persepsi, pikiran, ingatan, dan pengolahan informasi yang memungkinkan seorang memperoleh pengetahuan, memecahkan masalah, dan merencanakan masa depan atau semua proses psikologis yang berkaitan dengan bagaimana individu mempelajari, memperhatikan, mengamati, membayangkan, memperkirakan, menilai dan memikirkan lingkungannya.

Berdasarkan pendapat di atas dapat disimpulkan bahwa, Teori Kognitif adalah kegiatan untuk mengetahui pengetahuan yang dimiliki manusia yang 
berpusat pada susunan syaraf pada waktu manusia sedang berpikir. Teori kognitif dapat mengembangkan kemampuan berpikir anak untuk mendapat mengolah perolehan belajarnya baik logika dan pengetahuan ruang dan waktu.

\section{METODE}

Penulisan tentang Creative, Critical Thingking, Communicative, And Collaborative (4C) pada mata pelajaran Sejarah Indonesia kelas X IK di MAN 1 Solok ini menggunakan metode penelitian deskriptif kualitatif. Menurut (Sugiyono, 2005: 21) metode deskriptif adalah suatu metode yang digunakan untuk menggambarkan atau menganalisi suatu hasil penelitian tetapi tidak digunakan untuk membuat kesimpulan yang lebih luas. Adapun tujuan penelitian deskriptif adalah untuk menghasilkan gambaran tentang sebuah kelompok, menggambarkan mekanisme sebuah proses atau hubungan dengan memberikan gambaran yang lengkap serta menyajikan informasi dasar akan suatu hubungan. Jadi data yang diperoleh dari penelitian ini merupakan suatu usaha bersifat penjabaran dari fakta, kenyataan ataupun peristiwa. Dalam hal ini data yang akan diperoleh yaitu rancangan, pelaksanaan dan evaluasi pembelajaran 4C oleh guru Sejarah kelas X IK di MAN 1 Solok.

Penelitian ini dilaksanakan pada semester genap tahun ajaran 2020/2021, di MAN 1 Solok yang beralamat di jalan Guguak Panjang No. 35 Jorong Bawah Duku, Kab. Solok. Untuk mendapatkan keterangan dan data yang sesuai dengan penelitian yang diteliti, maka informan penelitiannya adalah guru mata pelajaran Sejarah Indonesia kelas X IK, dan peserta didik kelas X IK di MAN 1 Solok. Pernyataan dari masing-masing informan merupakan fakta-fakta yang dijadikan data.

Penelitian ini menggunakan teknik penggumpulan data seperti observasi, studi dokumentasi, dan wawancara. Teknik observasi banyak digunakan dalam penelitian sejarah dan deskriptif karena melalui pengamatan gejala atau fenomena penelitian dapat diamati dari dekat untuk dikumpulkan dan dicatat. Studi dokumentasi dilakukan terhadap Implementasi Creative, Critical Thingking, Communicative, And Collaborative (4C) Dalam Pendekatan Saintifik Pada Pembelajaran Sejarah Indonesia Kelas X IK Di MAN 1 Solok dengan bentukbentuk dokumen seperti Rencana Pelaksanaan Pembelajaran (RPP), dan dokumentasi foto atau video. Wawancara ini juga menggunakan beberapa alat wawancara berupa catatan lapangan dan panduan wawancara setelah dilakukan wawancara peneliti langsung menulis dan merekam dalam bentuk video hasil wawancara.

Penelitian ini menggunakan teknik analisa data seperti reduksi data, penyajian data, mengambil kesimpulan. Selama proses reduksi data, peneliti dapat memilih data mana yang akan digunakan dan mana yang dibuang serta data mana yang akan dikembangkan. Data yang diperoleh dilapangan cukup banyak, maka dari itu perlu dilakukan pencatatan secara cermat dan detail untuk itu dilakukan reduksi data. 


\section{HASIL PEMBAHASAN}

Berdasarkan penelitian rancangan pembelajaran yang digunakan materi dengan pendekatan saintifik yang menggunakan model 4C. Model tersebut adalah Pertama, Creative yaitu siswa mengumpulkan informasi terkait jalur perdagangan yang ada di Nusantara dalam bentuk gambar seperti peta jalur yang dilalui bersumber dari buku dan juga internet, kemudian dalam bentuk Mind Mapping gambar peta dan penjelasan dalam bentuk tulisan tentang jalur perdagangan di Nusantara yang berpedoman dari berbagai sumber yang ada seperti buku dan internet yang akurat. Kedua, Critical Thingking yaitu siswa menganalisis proses terbentuknya jaringan perdagangan di Nusantara seperti Jalur Sutra melalui India-Mongolia-Cina-Nusantara, kemudian Jalur Selat Malaka melalui India-Arab-Cina-Selat Malaka. Ketiga, Communicative yaitu siswa dapat mengemukakan dampak jaringan perdagangan di Nusantara. Keempat, Collaborative yaitu siswa dibagi menjadi beberapa kelompok untuk mendiskusikan terkait proses terbentuknya jaringan perdagangan di Nusantara, kegiatan itu diawali dengan mengamati dan menganalisispeta jalur jaringan perdagangan di Nusantara, kemudian menjelaskan proses terbentuknya jaringan perdagangan di Nusantara.

Pelaksanaan pembelajaran tatap muka menerapkan 4C pada aspek indikator Creative sudah diterapkan dengan guru memberikan siswa tugas membuat suatu karya berupa Mind Mapping semenarik mungkin, namun didalam observasi siswa tidak tampak mempresentasikan di depan kelas. Di indikator Critical Thingking telah dilakukan dengan cara guru memberikan pertanyaan kepada siswa secara acak yang menuntut siswa untuk berpikir kritis, namun siswa ditunjuk tidak dapat menjawab begitun siswa yang lainnya sehingga guru yang menjelaskannya. Di indikator Communication telah diterapkan dengan cara guru menanyakan pemahaman siswa terkait materi yang dipelajari, tetapi siswa belum dapat mengemukakan pemahamannya. Di indikator Collaborative guru bersama siswa menarik kesimpulan materi yang baru saja dibahas di kegiatan penutup.

Soal evaluasi yang digunakan guru untuk mengukur kemampuan siswa sudah menerapkan 4C dimana dari jenis soal yang digunakan guru sudah menggunakan tingkatan tinggi atau HOTS yang mana kategori soal HOTSini lebih memfokuskan Critical Thingking siswa untuk menjawab soal analisis yang tidak menggunakan bahasa buku. Selain itu untuk penilain keterampilan siswa, guru juga menunjang Creative siswa dengan memberikan tugas potofolio Mind Mapping semenarik mungkin sesuai dengan kreativitas siswa itu sendiri.

\section{KESIMPULAN}

Berdasarkan uraian yang telah dijelaskan di atas dapat ditarik kesimpulan, bahwa pembelajaran menggunakan Creative, Critical Thingking, Communicative and Collaborative (4C) ini di rancang dalam perangkat pembelajaran yaitu ke dalam RPP yang telah disusun guru mata pelajaran Sejarah Indonesia yang telah sesuai dengan pedoman peraturan yang diterapkan MAN 1 Solok. Materi yang dirancang dengan pendekatan saintifik yang menggunakan model 4C. Dalam pelaksanaan 4C indikator Creative terwujud dari tugas karya berupa Mind 
Mapping yang diberikan guru. Indikator Critical Thingking terwujud dengan adanya guru memberikan pertanyaan yang bersifat berpikir kritis kepada siswa yang telah ditunjuk bernama Mona, namun siswa tersebut tidak dapat menjawab begitu juga dengan siswa lainnya. Indikator Communicative terwujud dengan adanya guru menanyakan kepada siswa terkait pemahamannya terhadap materi. Indikator Collaborative terwujud pada kegiatan penutup yang mana guru bersama siswa menyimpulkan materi yang sudah dibahas. Untuk kegiatan evaluasi $4 \mathrm{C}$ yang digunakan guru untuk mengukur kemampuan siswa dapat dilihat dari jenis soal yang digunakan guru sudah menggunakan tingkatan tinggi atau HOTS yang mana kategori soal HOTS ini lebih memfokuskan Critical Thingking siswa untuk menjawab soal analisis yang tidak menggunakan bahasa buku. Selain itu untuk penilain keterampilan siswa, guru juga menunjang Creative siswa dengan memberikan tugas potofolio Mind Mapping semenarik mungkin sesuai dengan kreativitas siswa itu sendiri.

\section{DAFTAR PUSTAKA}

Arikunto, Suharsimi. 2010. Manajemen Penelitian. Jakarta: Rineka Cipta

Furchan ,Arief. 2011. Pengantar Penelitian Dalam Pendidikan. Yogyakarta: Pustaka Belajar

Jenner, Simarmata, dkk. 2020. Pendidikan Di Era Revolusi 4.0 : Tuntutan, Kompetensi dan Tantangan. Banten: Yayasan Kita Menulis

Nana, Syaodih. 2010. Metode Penelitian Pendidikan. Bandung: PT Remaja Rosdakarya

Sugiyono, 2015. Metode Penelitian \& Pengembangan. Bandung: Alfabeta

Sugiyono. 2016. Metode Penelitian : Kualitatif, Kuantitatif, Dan R\&D. Bandung: Alfabeta

Putri, Nugraheni. 2019. Analisis Keterampilan Berpikir Tingkat Tinggi Pada Pembelajaran Tematik Kelas V (Studi Kasus Di Salah Satu SD Swasta Kota Yogyakarta). Universitas Sanata Dharma Yogyakarta.

Lusinta, Saraswati. 2019. Integrasi Pembelajaran 4C Dalam Model Blended Learning Pada Materi Perbandingan Trigonometri Kelas X SMK Kawung 2 Surabaya. Universitas Wijaya Kusuma Surabaya.

Ida, Bagus Ariyana. 2019. Pembelajaran Untuk Meningkatkan Kompetensi 4C (Communicative, Collaborative, Critical Thingking, dan Creative Thingking) Untuk Menyongsong Era Abad 21. Universitas Pendidikan Ganesha. 